\title{
- Position of cardiac magnetic resonance imaging in clinical management of cardiomyopathies
}

\author{
Marko Boban* \\ Clinic for Treatment, \\ Rehabilitation and Prevention \\ of Cardiovascular Diseases, \\ Thalassoterapia Opatija, \\ Opatija, Croatia
}

KEYWORDS: cardiac magnetic resonance imaging, cardiomyopathy, diagnostic imaging CITATION: Cardiol Croat. 2017;12(4):133. | https://doi.org/10.15836/ccar2017.133

*ADDRESS FOR CORRESPONDENCE: Marko Boban, Thalassotherapia Opatija - Klinika za liječenje, rehabilitaciju i prevenciju bolesti srca i krvnih žila, Ul. Maršala Tita 188, HR-51410 Opatija, Croatia. / Phone: +385-51-202-720 E-mail: marcoboban@yahoo.com ORCID: Marko Boban, http://orcid.org/0000-0002-6129-575X

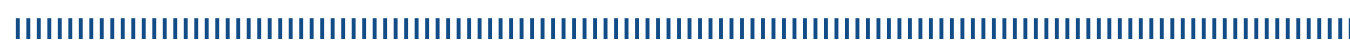
Cardiomyopathies are heterogeneous disorders of the heart muscle or function, which cause arrhythmias, sudden cardiac death or heart failure. Cardiac magnetic resonance imaging (CMR) recently became an important diagnostic tool for both diagnosing and clinical management of cardiomyopathies. By virtue of multiplanarity imaging, advanced temporal and spatial resolution, as well as functional assessment of systolic function, CMR offered important advancement to conventional imaging modalities. By virtue of tissue imagining, further knowledge was gained on pathophysiology of process, prognostic course of disease, and assessment of treatment applicability or efficiency. Controlled studies with prospective follow up reported on imperative position of CMR in management of cardiomyopathies, with reproducible and timely guided therapeutic interventions and well established relevance for improvement in the rates of major adverse outcomes. ${ }^{1-4}$ The most important facts on clinical management of cardiomyopathies using CMR will be presented in brief.
RECEIVED:

March 11, 2017

ACCEPTED:

April 6, 2017

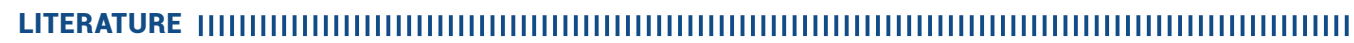

1. Rajiah P, Raza S, Saboo SS, Ghoshhajra B, Abbara S. Update on the Role of Cardiac Magnetic Resonance in Acquired Nonischemic Cardiomyopathies. J Thorac Imaging. 2016 Nov;31(6):348-366. https://doi.org/10.1097/RTI.0000000000000226

2. Yingchoncharoen T, Jellis C, Popovic ZB, Wang L, Gai N, Levy WC, et al. Focal fibrosis and diffuse fibrosis are predictors of reversed left ventricular remodeling in patients with non-ischemic cardiomyopathy. Int J Cardiol. 2016 0ct 15;221:498-504. https://doi.org/10.1016/j.ijcard.2016.06.095

3. Gaztanaga J, Paruchuri V, Elias E, Wilner J, Islam S, Sawit S, et al. Prognostic Value of Late Gadolinium Enhancement in Nonischemic Cardiomyopathy. Am J Cardiol. 2016 0ct 1;118(7):1063-8. https://doi.org/10.1016/j.amjcard.2016.06.059

4. Müller KA, Müller I, Kramer U, Kandolf R, Gawaz M, Bauer A, et al. Prognostic value of contrast-enhanced cardiac magnetic resonance imaging in patients with newly diagnosed non-ischemic cardiomyopathy: cohort study. PLoS One. 2013;8(2):e57077. https://doi.org/10.1371/journal.pone.0057077 